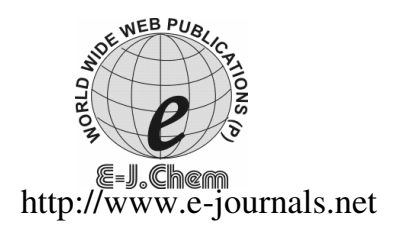

ISSN: 0973-4945; CODEN ECJHAO

E-Journal of Chemistry

2011, 8(3), 1462-1471

\title{
Extractive Spectrophotometric Determination of Bismuth(III) in Water Using Some Ion Pairing Reagents
}

\author{
ABDULAZIZ S. BASHAMMAKH \\ The Centre of Excellence in Environmental Studies \\ King Abdulaziz University, P. O. Box 80203 \\ Jeddah 21589, Kingdom of Saudi Arabia \\ abashammakh@kau.edu.sa
}

Received 30 September 2010; Revised 2 December 2010; Accepted 15 December 2010

\begin{abstract}
Two novel and low cost liquid-liquid extraction methods for the separation of bismuth(III) at trace level from aqueous medium have been developed. The two methods were based upon the formation of yellow colored ternary complex ion associates of tetraiodobismuth(III) complex anion, $\mathrm{BiI}_{4}{ }^{-}$ with the ion-pairing reagent 2,3,5-tetraphenyltetrazoliumchloride $\left(\mathrm{Tz}^{+} . \mathrm{Cl}^{-}\right)$and 1,10 phenanthroline (Phen) in sulfuric acid medium. The effect of various parameters e.g. $\mathrm{pH}$, organic solvent, shaking time, etc. on the preconcentration of bismuth(III) from the aqueous media by the reagent was investigated. The developed colored complex ion associates $\left[\mathrm{Tz}^{+} . \mathrm{BiI}_{4}{ }^{-}\right]$and $\left[\mathrm{Phen}^{+} . \mathrm{BiI}_{4}{ }^{-}\right]$were extracted quantitatively into acetone-chloroform $(1: 1 \mathrm{v} / \mathrm{v})$ and methylisobutylketone (MIBK), respectively. The compositions of the formed complex ion associates $\left[\mathrm{Tz}^{+} \cdot \mathrm{BiI}_{4}^{-}\right]$and $\left[\mathrm{Phen}^{+} \cdot \mathrm{BiI}_{4}^{-}\right]$were determined by the Job's method at 500 and $490 \mathrm{~nm}$, respectively. The plots of bismuth(III) concentration $\left(0-17 \mu \mathrm{g} \mathrm{m}^{-1}\right)$ versus absorbance of the associates at 500 and $490 \mathrm{~nm}$ were linear with good correlation coefficient $\left(\mathrm{R}^{2}=0.998\right)$. The developed method of the ion associate $\left[\mathrm{Tz}^{+} . \mathrm{BiI}_{4}{ }^{-}\right]$two methods was applied successfully for the analysis of bismuth in water.
\end{abstract}

Keywords: Bismuth determination, Ion pairing, Phenanthroline, Ion associate, Wastewater

\section{Introduction}

Bismuth presents in oxidation states 3 and 5. Compounds of bismuth(V) are not exist in solution and are very important in view of analytical chemistry ${ }^{1}$. Bismuth has been widely used for various industries e.g. pigment industry for coloring plastics and paints, batteries ${ }^{2}$ and ceramics ${ }^{3,4}$, semi-conductors, cosmetic preparations, alloys and as a carrier for U-235 or U233 fuel in nuclear reactors ${ }^{5}$. Its pharmaceutical uses have expanded to peptic ulcer treatments and topical dermatological creams ${ }^{6}$. The use of bismuth in industry and medicine increases therefore, its spread into our environment and the chance of its exposure to organism increased rapidly ${ }^{6,7}$. 
Numerous procedures have been described for the determination of bismuth in pharmaceutical products employing EDTA titration and a variety of indicators e.g. pyrocatechol violet, methylthymol blue, eriochrome black $\mathrm{T}$, thioura, xylenol orange, the last being used in the current British Pharmacopoia method ${ }^{8}$. The tetraiodobismuthate anion has been extracted directly with several onium cations e.g. $\left(\mathrm{C}_{6} \mathrm{H}_{5}\right)_{4} \mathrm{P}^{+},\left(\mathrm{C}_{6} \mathrm{H}_{5}\right)_{4} \mathrm{As}^{+}$and benzyldimethylphenyl ammonium into a variety of organic solvents ${ }^{9,10}$. A liquid - liquid extractive spectrophotometric method has been reported for bismuth(III) determination as tetra- $n$ butylammonium tetraiodo bismuth(III) in chloroform ${ }^{11}$. Atomic absorption spectrometry and flow-injection hydride generation atomic absorption spectrometry using sodium tetrahydrocarbonate as reductant have been reported for bismuth determination in geological materials ${ }^{11-13}$. A new chromogenic reagent 2-(2-arsonophenylazo)-1, 8-dihydroxynaphthaline-3,6-disulphonic acid (2,6-dichloroar-senazo) has been synthesized and successfully used for the spectrophotometric determination of bismuth ${ }^{14}$. The present manuscript reports low cost extractive spectrophotometric methods for the separation and subsequent determination of bismuth species in water samples as tetraiodo bismuthate(III) using the ion pairing reagent $\mathrm{Tz}^{+} . \mathrm{Cl}^{-}$and Phen. The most probable extraction mechanism and composition of the developed complex ion associates were assigned and properly addressed.

\section{Experimental}

A Shimadzu double beam UV-VIS (UV-160 7 pc) spectrophotometer with quartz cell (10 mm) was used for recording the UV -Visible spectra and the absorbance of the produced complex ion associates. Infrared (IR) spectra were recorded on a Broker FT-IR spectrophotometer model IFS 66. Perkin Elmer inductively coupled plasma - optical emission spectrometer (ICP- OES, Optima 4100 DC (Shelton, CT, USA) and inductively coupled plasma - mass spectrometer (ICP - MS) Sciex model Elan DRC II (California, CT, USA) were used to measure ultra trace concentrations of bismuth in the aqueous phase after solvent extraction at the optimum operational parameters (Table 1). A Milli-Q waters plus system (Milford, MA, USA) and a thermo fisher scientific Orion model $720 \mathrm{pH}$ Meter were used for water supply and $\mathrm{pH}$ measurements, respectively. Microanalyses of $\mathrm{C}, \mathrm{H}, \mathrm{N}$ and I was performed on a Perkin-Elmer $240 \mathrm{C}$ elemental analyzer.

Table 1. ICP-OES operational conditions and wavelength $(\mathrm{nm})$ for bismuth determination*

\begin{tabular}{lc}
\hline Parameter & \\
\hline $\mathrm{R}_{\mathrm{f}}$ power (kW) & $1050(900.0)$ \\
Plasma gas (Ar) flow rate, $\mathrm{L} \mathrm{min}^{-1}$ & $15(15)$ \\
Auxiliary gas (Ar) flow rate, $\mathrm{L} \mathrm{min}^{-1}$ & $0.2(1.2)$ \\
Nebulizer gas (Ar) flow rate, $\mathrm{Lmin}^{-1}$ & $0.80(0.93)$ \\
Pump rate, mL min & -1 \\
Observation height, $\mathrm{mm}$ & 1.5 \\
Integration time, $\mathrm{s}$ & 15 \\
Wavelength, $\mathrm{nm}$ & 10 \\
\hline
\end{tabular}

${ }^{*} I C P-M S$ operational parameters are given in parentheses. Other ICP-MS parameters are: lens voltage $=9.0$; analog stage voltage 1750.0; pulse stage voltage $=750$; quadrupole rod offset $s t d==0.0 ;$ cell rod offset $=-18.0 ;$ Discriminator threshold $=17.0 ;$ Discriminator threshold $=-17.0$; cell path voltage $S t d=-13.0$ and atomic mass 208.98

\section{Reagents and solutions}

All chemicals and solvents used were of analytical reagent grade and were used without further purification. A stock solution $(1 \mathrm{mg} / \mathrm{mL})$ of bismuth(III) sub carbonate was prepared 
by dissolving an accurate weight $(0.13 \mathrm{~g})$ of the salt in $3 \mathrm{HCl}(3 \mathrm{~mL})$ then diluted to $100 \mathrm{~mL}$ with de ionized water. More diluted solutions of bismuth(III) species were prepared in de ionized water in the presence of few drops of nitric acid as required. Stock solutions $(1.5 \% \mathrm{w} / \mathrm{v})$ of $2,3,5$ tetraphenyl- $2 \mathrm{H}$-tetrazoliumchloride and 1,10 phenanthroline were prepared in water and the minimum amount of ethanol and completed with de ionized water to the mark, respectively. BDH potassium iodide-ascorbic acid (Poole, England) reagent was prepared by mixing $\mathrm{KI}(5 \mathrm{~g})$ and ascorbic acid (5) in water and diluting to $100 \mathrm{~mL}$.

\section{General procedures}

\section{Extraction with 2, 3, 5 tetraphenyl-2-H-tetrazoliumchloride}

An aliquot $(3.0 \mathrm{~mL})$ containing $1-15 \mu \mathrm{g} \mathrm{mL} \mathrm{m}^{-1}$ of bismuth(III) was placed in $100 \mathrm{~mL}$ separating funnel $(50 \mathrm{~mL})$ and $2 \mathrm{~mL} \mathrm{H}_{2} \mathrm{SO}_{4}\left(1.0 \mathrm{~mol} \mathrm{~L}^{-1}\right), 3 \mathrm{~mL}$ of $\mathrm{KI}$ - ascorbic acid reagent solution reagent and $1 \mathrm{~mL} \mathrm{Tz}$. $\mathrm{Cl}^{-}$were added in order. The test solution was diluted to $25 \mathrm{~mL}$ with de ionized water and shaken well with $5 \mathrm{~mL}$ of the mixed solvent (acetonechloroform $1: 1 \mathrm{v} / \mathrm{v})$ for $3 \mathrm{~min}$ in the presence of anhydrous sodium sulfate $(0.5 \mathrm{~g})$. After separation of the layers, the organic extract was separated out and its absorbance was measured at $500 \mathrm{~nm}$ against the reagent blank.

\section{Extraction with 1, 10 phenanthroline}

An aliquot $\left(3.0 \mathrm{~mL}\right.$ ) containing bismuth(III) in the concentration range $0.05-15 \mu \mathrm{g} \mathrm{mL}^{-1}$ was transferred into separating funnel $(50 \mathrm{~mL})$ and $2 \mathrm{~mL} \mathrm{H}_{2} \mathrm{SO}_{4}\left(1.0 \mathrm{~mol} \mathrm{~L}^{-1}\right), 3 \mathrm{~mL}$ of KI ascorbic acid reagent and $1 \mathrm{~mL}$ Phen $(0.05 \% \mathrm{~m} / \mathrm{v})$ were added. The test solution was diluted to $25 \mathrm{~mL}$ with de ionized water and shaken well with $5 \mathrm{~mL}$ MIBK $(1: 1 \mathrm{v} / \mathrm{v})$ for $2 \mathrm{~min}$. After equilibrium, the floated complex ion associate between the two phases was separated out and re-dissolved in acetone $(3 \mathrm{~mL})$ acidified with $\mathrm{H}_{2} \mathrm{SO}_{4}\left(0.1 \mathrm{~mol} \mathrm{~L}^{-1}\right)$ and its absorbance was finally measured at $490 \mathrm{~nm}$ against the reagent blank.

\section{Results and Discussion}

\section{Absorption UV visible spectra of developed colored complex species}

In acid medium $\left(0.2-2 \mathrm{~mol} \mathrm{~L}^{-1}\right)$ and in the presence of an excess of iodide, bismuth forms the orange yellow complex $\mathrm{BiI}_{4}^{-15} \cdot{ }^{-15}$. The absorption spectrum (Figure 1) of the bismuth(III) iodide complex $\left[\mathrm{BiI}_{4}\right]^{-}$exhibits an intense maximum at $337 \mathrm{~nm}\left(2.045 \times 10^{4} \mathrm{~L} \mathrm{~mol}^{-1} \mathrm{~cm}^{-1}\right)$ and a less intense peak at $465 \mathrm{~nm}\left(3.06 \times 10^{3} \mathrm{~L} \mathrm{~mol}^{-1} \mathrm{~cm}^{-1}\right)$ Figure 1. On mixing tetraiodobismuth(III) complex with the reagent $\mathrm{TZ}^{+} . \mathrm{Cl}^{-}$or Phen in $\mathrm{H}_{2} \mathrm{SO}_{4}\left(1.0\right.$ mol L $\left.\mathrm{L}^{-1}\right)$ and shaking for few minutes with chloroform $(1: 1 \mathrm{v} / \mathrm{v})$, orange red complex ion associates were developed in the organic phases.

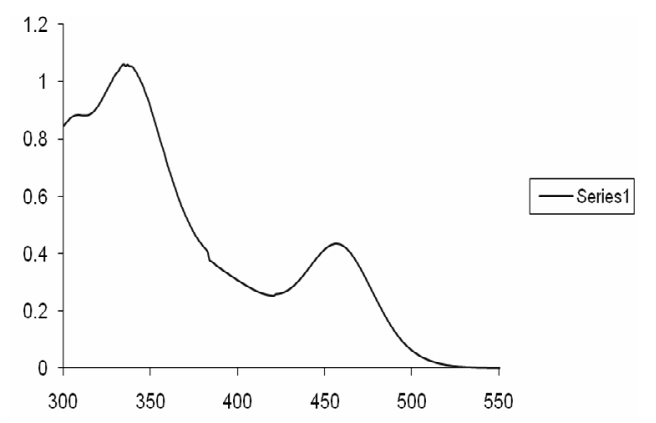

Figure 1. Absorption spectrum of the complex anion $\left[\mathrm{BiI}_{4}\right]^{-}$in water 

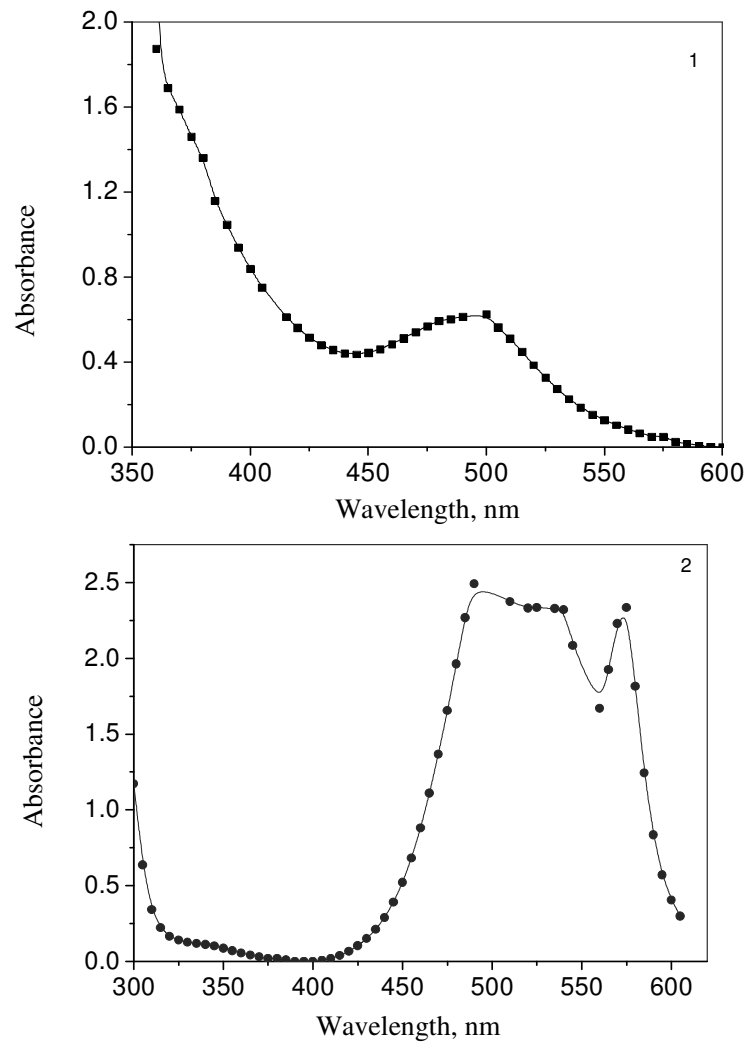

Figure 2. Absorption spectra of the developed complex associates $[\mathrm{Tz}]^{+}$. $\left[\mathrm{BiI}_{4}\right]^{-}$in acetone chloroform (1) and $[\mathrm{Phen}]^{+}$.[BiI $\left.]_{4}\right]^{-}$in acetone (2)

The absorption spectra of the developed yellow colored species of $\left[\mathrm{BiI}_{4}\right]^{-}$with $\mathrm{Tz}^{+} \mathrm{Cl}^{-}$in acetone - chloroform (1) and Phen in acetone (2) after extraction with MIBK and dissolving the colored scum are shown in Figure 2. The spectra of the associates of $\left[\mathrm{BiI}_{4}\right]^{-}$with $\mathrm{Tz}^{+} \mathrm{Cl}^{-}$ in acetone - chloroform and the floated scum of Phen in acetone showed maximum absorbance at $500 \mathrm{~nm}$ and $490 \mathrm{~nm}$, respectively.

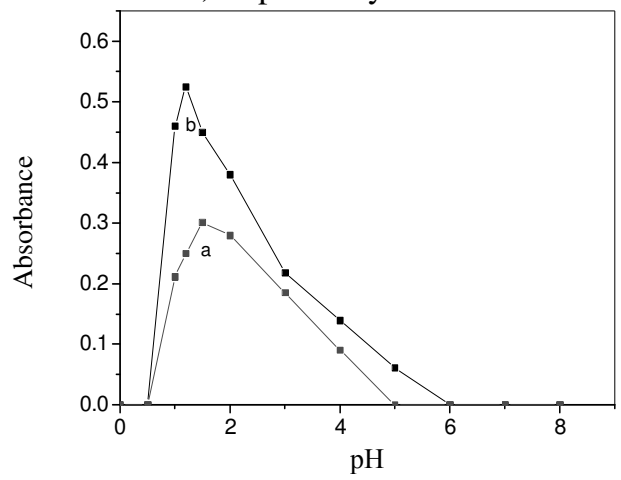

Figure 3. Influence of $\mathrm{pH}$ on the extraction of the complex ion associates $[\mathrm{Tz}]^{+}$. $\left[\mathrm{BiI}_{4}\right]^{-}$in acetone-chloroform $(1: 1 \mathrm{v} / \mathrm{v})(\mathrm{a})$ and $[\mathrm{Phen}]^{+} .\left[\mathrm{BiI}_{4}\right]^{-}$in acetone (b) 


\section{Influence of analytical parameters on bismuth(III) extraction}

The influence of $\mathrm{pH}$ of the aqueous phase on the extraction of the complex ion associate of bismuth(III) with the reagents $\mathrm{Tz}^{+} . \mathrm{Cl}^{-}$and Phen was studied by measuring the absorbance of the extracted complex ion associates in the solvent system acetone chloroform $(1: 1 \mathrm{v} / \mathrm{v})$ and acetone at 500 and $490 \mathrm{~nm}$, respectively. The final $\mathrm{pH}$ of each aqueous solution was adjusted with dilute $\mathrm{HCl}$ and/or $\mathrm{NaOH}$ before the extraction. The results are demonstrated in Figure 3. Maximum extraction of the produced ion associates were achieved at $\mathrm{pH} \sim 1-2$. At $\mathrm{pH} \sim 1-2$, bismuth(III) ions are able to form the stable complex anion $\left[\mathrm{BiI}_{4}\right]^{-}$which in turn form soluble ternary complex ion associates with $\mathrm{TZ}^{+} . \mathrm{Cl}^{-}$and Phen in non polar solvents. At $\mathrm{pH}>2$, a significance decrease in the absorbance of the extracted species was achieved and attributed to the decrease in the complex formation of the complex anion $\left[\mathrm{BiI}_{4}\right]^{-}$and also the hydrolyzed species $\mathrm{BiOH}^{2+}$ or $\mathrm{BiO}^{+}$or $\mathrm{BiOCl}$. Formation of non extractable species of bismuth(III) in the organic solvents at $\mathrm{pH}>2$ may also account for the observed trend.

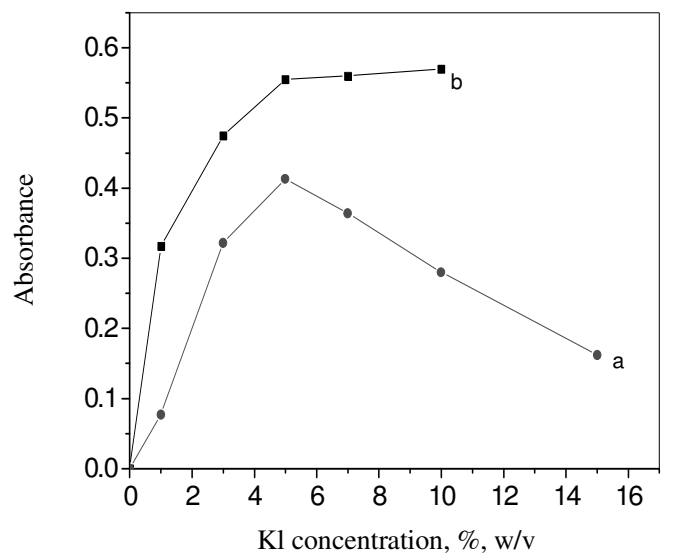

Figure 4. Effect of KI on the extraction of the complex ion associates $[\mathrm{Tz}]^{+}$. $\left[\mathrm{BiI}_{4}\right]^{-}$in acetone - chloroform (a) and $[\mathrm{Phen}]^{+}$. $\left[\mathrm{BiI}_{4}\right]^{-}$in acetone (b)

The influence of mineral acids e.g. $\mathrm{HCl}, \mathrm{H}_{2} \mathrm{SO}_{4}, \mathrm{HNO}_{3}$ and $\mathrm{H}_{3} \mathrm{PO}_{4}$ in the concentration range $0.05-2.0 \mathrm{~mol} \mathrm{~L}^{-1}$ was examined as extraction media for the extraction of bismuth(III) with $\mathrm{Tz}^{+} \mathrm{Cl}^{-}$and Phen in the presence of $\mathrm{KI}$-ascorbic acid mixture. The absorbance (A) of the developed extracted colored species in the organic phase increased in the following order:

$\mathrm{H}_{2} \mathrm{SO}_{4}(\mathrm{~A}=0.45)>\mathrm{HCl}(\mathrm{A}=0.21)>\mathrm{HNO}_{3}(\mathrm{~A}=0.15)>\mathrm{H}_{3} \mathrm{PO}_{4}(\mathrm{~A}=0.09)$

and maximum extraction was achieved in $\mathrm{H}_{2} \mathrm{SO}_{4}\left(0.1 \mathrm{~mol} \mathrm{~L} \mathrm{~L}^{-1}\right)$. Thus, sulfuric acid at concentration $0.1 \mathrm{~mol} \mathrm{~L}^{-1}$ was adopted in the subsequent work.

The influence of KI concentrations on the formation and extraction of the ion associate of tetraiodobismuthate(III) with $\mathrm{Tz}^{+} . \mathrm{Cl}^{-}$and Phen was critically investigated and the results are demonstrated in Figure 4. Maximum absorbance and extraction of the formed complex ion associates were achieved at KI concentration up to $5 \%(\mathrm{w} / \mathrm{v})$ followed by a sharp decrease at higher KI concentration. At KI concentration $>5 \%$, significant decrease in the absorbance was noticed at $500 \mathrm{~nm}$ for $\mathrm{Tz}^{+} . \mathrm{Cl}^{-}$. This behavior is most likely attributed to the possible formation of binary complex ion associate between iodide ion and the $\mathrm{Tz}^{+} . \mathrm{Cl}^{-}$reagent 
forming the ion associate $\mathrm{TZ}^{+} . \mathrm{I}^{-}$which competes effectively with extraction of the complex anion $\left[\mathrm{BiI}_{4}\right]^{-}$with $\mathrm{Tz}^{+} . \mathrm{I}^{-}$reagent. On the other hand, KI may be oxidized by areal oxidation to iodine which also extracted onto the organic phase and competes with $\left[\mathrm{BiI}_{4}\right]^{-}$ with $\mathrm{TZ}^{+} . \mathrm{I}^{-}$associate. The atmospheric oxidation of iodide ion was minimized by ascorbic acid $(1 \% \mathrm{w} / \mathrm{v})$ in the test aqueous solution. In the case of 1,10 phenanthroline reagent, maximum extraction was achieved at KI concentration of 5\% (w/v) and remained constant (Figure 4).

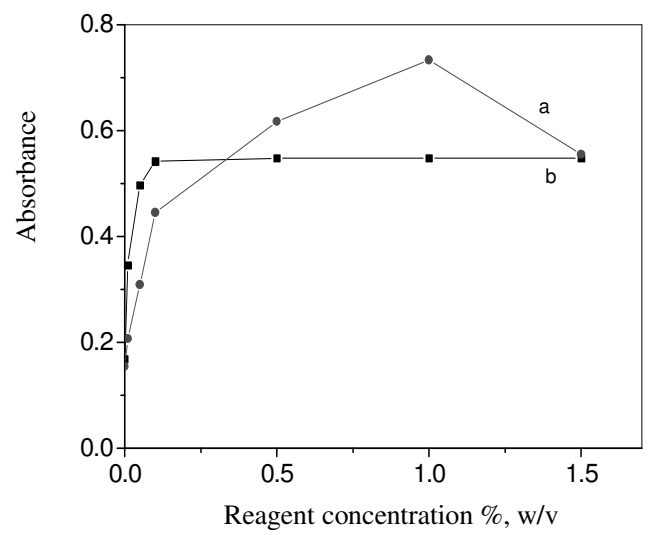

Figure 5. Effect of concentration of the reagent $\mathrm{Tz}^{+} \mathrm{Cl}^{-}$(a) and Phen (b) on the extraction of the produced complex ion associates of tetraiodobismuthate

The influence of the reagents $\mathrm{Tz}^{+} \mathrm{Cl}^{-}$and Phen concentrations on bismuth(III) extraction from the iodide media was investigated and the results are shown in Figure 5. Maximum absorbance was achieved at $1 \%(\mathrm{w} / \mathrm{v}) \mathrm{Tz}^{+} \mathrm{Cl}^{-}$concentration followed by a sharp decrease at higher reagent concentrations. The increase in the uptake of the developed ion associate at $1 \%(\mathrm{w} / \mathrm{v}) \mathrm{Tz}^{+} \mathrm{Cl}^{-}$concentration may be assigned to the ease of formation of the complex ion associate of $\mathrm{Tz}^{+} \mathrm{Cl}^{-}$with $\left[\mathrm{BiI}_{4}\right]^{-}$.

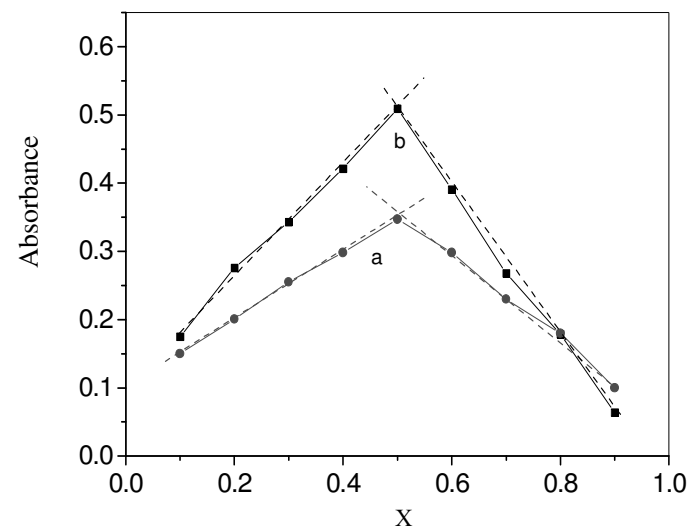

Figure 6. Jobs continuous variation plot for the complex ion associate of bismuth(III) with the ion pairing reagent $\mathrm{Tz}^{+} . \mathrm{Cl}^{-}$

The absence of any competition from other co - existence species in the extraction

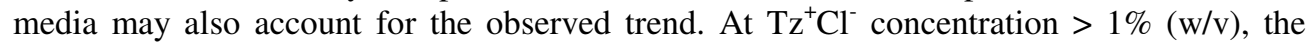
formation of the binary ion associate between iodide ion and the reagent $\mathrm{Tz}^{+} \mathrm{Cl}^{-}$may be 
enhanced and competes with the associate of $\mathrm{TZ}^{+} . \mathrm{Cl}^{-}$with $\left[\mathrm{BiI}_{4}\right]^{-}$. For Phen reagent, maximum extraction of its associate with $\left[\mathrm{BiI}_{4}\right]^{-}$was achieved at $0.01 \%(\mathrm{w} / \mathrm{v})$ reagent concentration and remained constant.

A variety of organic solvents e.g. methylisobutylketone (MIBK), $n$-hexane, chloroform, toluene, diethylether and ethylacetate was tested for the extraction of the ternary complex ion associates of bismuth(III) with $\mathrm{Tz}^{+} \mathrm{Cl}^{-}$and Phen using general recommended procedures. Both MIBK and the solvent system acetone- chloroform $(1: 1 \mathrm{v} / \mathrm{v})$ effectively extracted the ion associates of bismuth(III) with $\mathrm{Tz}^{+} \mathrm{Cl}^{-}$and Phen. The associate of $\left[\mathrm{BiI}_{4}\right]^{-}$with Phen was floated onto MIBK and the he floated layer (scum) was re dissolved in acetone and its absorbance at $490 \mathrm{~nm}$ was measured. The stability of the extracted ion associates was also tested by measuring their absorbance at various time intervals. The extracted complex ion associates were found stable for up to $24 \mathrm{~h}$ day light and stable for $3 \mathrm{~h}$ in direct sunlight.

\section{Figure of merits of the developed analytical metods of bismuth(III) extraction}

Under the optimum experimental conditions, the molar absorptivity of the ion associates of bismuth(III) with $\mathrm{Tz}^{+} . \mathrm{Cl}^{-}$and Phen at 500 and $490 \mathrm{~nm}$ were found equal $1.74 \pm 0.02 \times 10^{4}$ and $2.14 \pm 0.002 \mathrm{~L} \mathrm{~mol}^{-1} \mathrm{~cm}^{-1}$, respectively. Beer's law plots were obeyed in the concentration range $0.02-15$ and $0.05-17 \mu \mathrm{g} \mathrm{mL}^{-1}$ bismuth (III) using the reagents $\mathrm{Tz}^{+} . \mathrm{Cl}^{-}$and Phen in aqueous iodide media, respectively. The Sandell's sensitivity index ${ }^{16}$ of the associate of bismuth(III) with $\mathrm{Tz}^{+} . \mathrm{Cl}^{-}$at $500 \mathrm{~nm}$ was $0.063 \mu \mathrm{g} \mathrm{cm}{ }^{-2}$, while for bismuth(III) - Phen associate at $490 \mathrm{~nm}$ it was found equal $0.074 \mu \mathrm{g} \mathrm{cm}^{-2}$, respectively. Least square analysis of the studied concentration range of bismuth(III) using $\mathrm{Tz}^{+} . \mathrm{Cl}^{-}$and Phen yielded the following regression equations:

$$
\begin{aligned}
& \mathrm{A}_{500}=0.07894 \mathrm{C}-0.0129 \\
& \mathrm{~A}_{490}=0.09078 \mathrm{C}+0.0119
\end{aligned}
$$

Where, $\mathrm{C}$ is the bismuth(III) concentration $\left(\mu \mathrm{g} \mathrm{mL}^{-1}\right)$ with correlation coefficients $(\mathrm{R})$ in the range 0.998-0.999. The effective concentration range of bismuth(III) as evaluated from Ringbom's plots ${ }^{15}$ are the established standard adopted to know the optimum range of effective concentration for systems that obeyed Beer's law. The plots drawn between $\log \mathrm{C}$ of bismuth(III) and 1-T, where $T$ is the transmittance have sigmoid shape with linear segments at intermediate absorbance and concentration range of $0.06-12$ and $1-15 \mu \mathrm{g} \mathrm{mL}^{-1}$ bismuth(III) with $\mathrm{Tz}^{+}$. $\mathrm{Cl}^{-}$and Phen, respectively.

The value of the lower limit of detection $\left(\mathrm{LOD}=3 S_{y / x} / b\right)^{17}$ where, $S_{y / x}$ is the standard deviation of $y$-residual and $b$ is the slope of the calibration plot were found equal 0.008 and $0.009 \mu \mathrm{g} \mathrm{mL}{ }^{-1}$ bismuth(III) for the complex ion associates of $\mathrm{Tz}^{+} . \mathrm{Cl}^{-}$and Phen, respectively. The LOD could be improved to lower value by increasing the sample volume of the aqueous phase containing trace or ultra trace concentrations of bismuth(III) and $\mathrm{Tz}^{+} \cdot \mathrm{Cl}^{-}$or Phen under the optimum experimental conditions. The relative standard deviation of five measurements, at $2 \mu \mathrm{g} \mathrm{mL}{ }^{-1}$ bismuth(III) employing the reagent $\mathrm{Tz}^{+} . \mathrm{Cl}^{-}$and Phen was $2.1 \pm 0.3$ and $2.3 \pm 0.16$, respectively. The figure of merits (LOD, linear range, RSD) of the procedure was better than compared successfully with many of the reported spectrometric methods ${ }^{9-11}$. The time consuming on the developed method was compared successfully with some of the reported methods ${ }^{12}$ confirming its precision.

\section{Characterization of the complex ion associate of bismuth (III) with $\mathrm{TZ}^{+}$.Cl and Phen}

The chemical composition of the formed complex ion-associates of bismuth(III) with the reagents $\mathrm{Tz}^{+} . \mathrm{Cl}^{-}$and Phen was determined by Jobs continuous variation method ${ }^{18}$ and the results 
are demonstrated in Figures 6 and 7, respectively. A 1:1 molar ratio of bismuth(III) to $\mathrm{Tz}^{+} . \mathrm{Cl}^{-}$or Phen in their complex ion associates was obtained. The stiochiometry of the associates were confirmed by plotting $\log \mathrm{K}_{\mathrm{D}}$ versus $\log [\mathrm{R}]$ according to the following equation ${ }^{19,20}$ :

$$
\log D_{B i}=\log K_{D}+\log \beta+\log [R]
$$

Where, $\mathrm{R}=\mathrm{Tz}^{+} \cdot \mathrm{Cl}^{-}$or Phen and $\mathrm{D}$ is the distribution ratio of bismuth(III) at the initial concentration $\left(1 \times 10^{-6} \mathrm{~mol} \mathrm{~L}^{-1}\right)$ in the aqueous iodide media $(\mathrm{pH} \mathrm{1-2)}$ at various reagent $(\mathrm{R})$ concentrations $\left(1.0-40.0 \times 10^{-5} \mathrm{M}\right)$. The plots of $\log \mathrm{D}_{\mathrm{Bi}}$ versus $\log [\mathrm{R}]$ were found linear (Figures $7 \& 8$ ) with a slope in the range 0.91-0. 98 confirming the formation of 1:1 molar ratio of bismuth(III) to reagent.

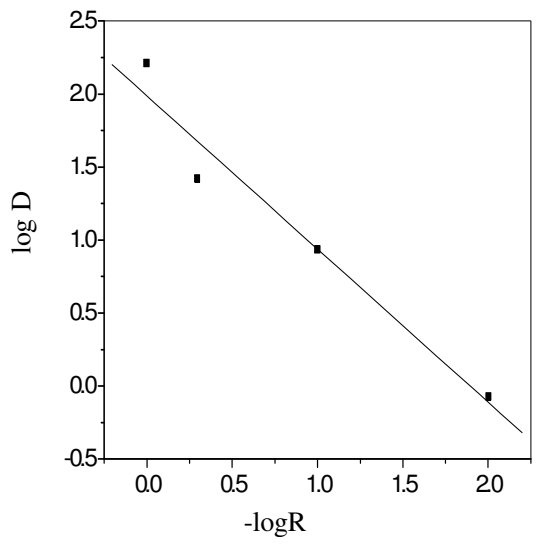

Figure 7. Plot of $\log \mathrm{D}$ versus $\log \left[\mathrm{Tz}^{+} . \mathrm{Cl}^{-}\right]$ of bismuth(III) extraction from aqueous KI medi at $\mathrm{pH} 1.2$ into the organic phase.

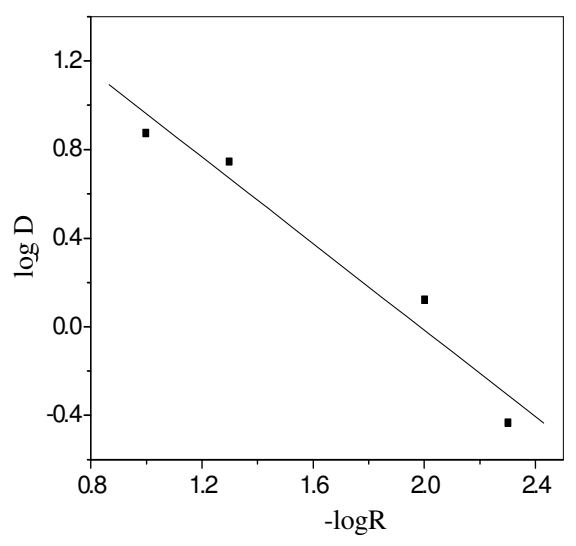

Figure 8. Plot of $\log \mathrm{D}$ versus $\log \left[\mathrm{Phen}^{-}\right]$ of bismuth(III) extraction from aqueous KI media at $\mathrm{pH} 1.2$ onto the organic phase.

The solid complex ion associate of bismuth(III) with $\mathrm{Tz}^{+} . \mathrm{Cl}^{-}$was isolated from the organic phase after with rotary evaporator. The produced complex associates $\left[\mathrm{Tz}^{+} \mathrm{BiI}_{4}{ }^{-}\right]$ and $\left[\mathrm{Phen}^{+} \mathrm{BiI}_{4}^{-}\right]$were then characterized from their elemental analysis. Analytical data for $\left[\mathrm{Tz}^{+}{ }^{+} \mathrm{BiI}_{4}{ }^{-}\right.$]: Found: $\mathrm{C}=22.79, \mathrm{H}=1.54, \mathrm{~N}=5.62, \mathrm{I}=50.63$; Calculated for $\mathrm{C}_{19} \mathrm{H}_{15} \mathrm{~N}_{4} \mathrm{BiI}_{4}$ : $\mathrm{C}=22.52, \mathrm{H}=1.48, \mathrm{~N}=5.53, \mathrm{I}=49.62$. Analytical data for $\left[\mathrm{Phen}^{+} \mathrm{BiI}_{4}{ }^{-}\right]$: Found: $\mathrm{C}=20.79$, $\mathrm{H}=0.92, \mathrm{~N}=3.1, \mathrm{I}=54.23$; calculated for $\mathrm{C}_{16} \mathrm{H}_{8} \mathrm{~N}_{2} \mathrm{BiI}_{4}: \mathrm{C}=20.4, \mathrm{H}=0.85, \mathrm{~N}=2.9$, $\mathrm{I}=53.3$. These data confirmed the formation of 1: 1 molar ratio of bismuth(III) to the reagent $\mathrm{Tz}^{+} . \mathrm{Cl}^{-}$or Phen achieved from the plot of $\log \mathrm{K}_{\mathrm{D}}$ versus $\log [\mathrm{R}]$ by the electronic spectra ${ }^{19,20}$. The IR spectra of the reagent $\mathrm{Tz}^{+} . \mathrm{Cl}^{-}$, Phen and their isolated solid ion associates recorded separately in $\mathrm{KBr}$ discs showed the characteristic vibrations at 1636 (s), 1608 and $450 \mathrm{~cm}^{-1}$ which are safely assigned to $v(\mathrm{~N}-\mathrm{N}), v(\mathrm{C}=\mathrm{N})+(\mathrm{C}-\mathrm{N})$ and $v(\mathrm{Bi}-\mathrm{I})$ vibrations $^{21}$, respectively confirming the proposed chemical structures of the developed associates.

\section{Effect of diver's ions on the absorbance of the developed colored species of bismuth(III)}

The influence of a relatively high excess $(1 \mathrm{mg})$ of some diver's ions which are often accompanied with the analyt ion e.g. $\mathrm{Li}^{+}, \mathrm{Na}^{+}, \mathrm{K}^{+}, \mathrm{Ba}^{2+}, \mathrm{Ca}^{2+}, \mathrm{Cu}^{2+}, \mathrm{Pb}^{2+}, \mathrm{Ni}^{2+}, \mathrm{Co}^{2+}, \mathrm{Cd}^{2+}$, $\mathrm{Zn}^{2+}, \mathrm{Hg}^{2+}, \mathrm{Cr}^{3+}, \mathrm{SO}_{4}{ }^{2-}, \mathrm{Cl}^{-}, \mathrm{Br}^{-}$and $\mathrm{PO}_{4}{ }^{3-}$ on the extraction of the ion associate of bismuth(III) with the reagent $\mathrm{Tz}^{+} . \mathrm{Cl}^{-}$was investigated. The tolerance limit (w/w) was set as the amount of foreign ion causing an error $\pm 3 \%$ in the extraction. A percentage recovery of $96 \pm 1.5 \%$ with a standard deviation of \pm 0.3 was achieved. The ions $\mathrm{Cu}^{2+}, \mathrm{Cd}^{2+}, \mathrm{Hg}^{2+} \mathrm{Pd}^{2+}, \mathrm{Cl}^{-}$and 
$\mathrm{Br}^{-}$are interfered seriously. Moreover, the solution must be free from large amounts of thallium (I), tin, arsenic, antimony, gold, silver, platinum and from elements in sufficient quantity to color the solution e.g., nickel.

\section{Analysis of bismuth in water samples}

The validity of the proposed $\mathrm{Tz}^{+} . \mathrm{Cl}^{-}$method for bismuth(III) determination at trace concentrations spiked to various (tap, lake and wastewater) water samples was tested by comparison with the results obtained by inductively coupled plasma mass spectrometry (ICP-MS). The tested water samples $(0.5 \mathrm{~L})$ were collected, filtered through a $0.45 \mu \mathrm{m}$ membrane filter and adjusted to $\mathrm{pH} 2$. An accurate amount $(0.0-15 \mu \mathrm{g})$ of bismuth(III) species were spiked individually into the water sample $(0.5-1.0 \mathrm{~L})$ and shaken well following the recommended procedures. The extracted bismuth(III) species were determined with the aid of the standard curve constructed under the same experimental conditions as described earlier. The data obtained are summarized in Table 2. The $F(0.075)$ ) and $t(1.91)$ tests at $5 \mu \mathrm{g} \mathrm{mL}^{-1}$ bismuth(III) determined by the developed method and by the standard dithizone method ${ }^{17}$ showed no significant differences in accuracy.

Table 2. Analysis of bismuth(III) different water samples

\begin{tabular}{ccc}
\hline Water sample & $\begin{array}{c}\text { Bi(III) added, } \\
\mu \mathrm{g} \mathrm{mL}^{-1}\end{array}$ & $\begin{array}{c}\text { Bismuth(III) found, } \\
\mu \mathrm{g} \mathrm{mL}^{-1}\end{array}$ \\
\hline Tap water & 10 & $9.7 \pm 0.032$ \\
Lake water & 10 & $10.2 \pm 0.19$ \\
Wastewater & 10 & $9.76 \pm 0.31$ \\
\hline
\end{tabular}

\section{Conclusion}

The developed extractive spectrophotometric procedures for bismuth(III) determination in aqueous media does not involve any stringent reaction conditions and provided simple and inexpensive approach for bismuth(III) determination. The developed ion associates are stable and short time is needed in the determination step of bismuth(III) in water. Both methods are applicable for bismuth(III) determination in fresh water. Thus, the method can certainly be placed among the most sensitive ones. Work is continuing for application of the developed methods for the chemical speciation of bismuth(III \& V) in environmental water samples.

\section{References}

1. Busev A I, Tiptsova V G and Ivanov M V, Analytical Chemistry of Rare Elements, Moscow, Rusian Edn., 1981, 341-350.

2. Gumus G, Filik H and Demirata B, Anal Chim Acta, 2005, 547, 138.

3. Sousa V C, Morlli M R and Kiminami R H G, Ceram Int., 2000, 26(5), 561-564.

4. Skidan B S, Glass Ceram., 2003, 60,339.

5. Yamani Y, Chaloosi M and Ebrahimzadeh H, Talanta, 2002, 56,797.

6. Abbaspour A and Baramakeh L, Talanta, 2005, 65(3), 692-699.

7. Tzanavaras P D, Themelis D G and Economou A, Anal Chim Acta, 2004, 505, 167-171.

8. Burns D T and Dangolle C D P, Anal Chim Acta, 1997, 337, 113.

9. Burns D T and Dunford M D, Anal Chim Acta, 1996, 334, 209.

10. Barakat S A, Harriott M and Burns D T, Anal Chim Acta, 1992, 258, 167.

11. Hasebe K and Tag M, Talanta, 1982, 29, 1135.

12. Venkaji K, Naiadu P P and Rao T J P, Talanta, 1994, 41, 1281. 
13. Liu H M, Chen S Y, Chang P H and Tsai S J, Anal Chim Acta, 2002, 459, 161.

14. Zhang H S, Zhang J F, Wang H and Li X Y, Anal Chim Acta, 1999, 380, 101.

15. Marczenko Z, Spectrophotometric Determination of Elements, $3^{\text {rd }}$ Edition, Ellis Horwood, Chichester, UK, 1986, 68-70.

16. Sandell E B, Colorimetric Determination of Trace Metals, Interscience, New York, 1959.

17. Miller J C and Miller J N, Statistics for Analytical Chemistry, $4^{\text {th }}$ Ed., Ellis Horwood, New York, 1994, pp.115-121.

18. Sawyer D T, Heineman W R and Beebe J M, Chemistry Experiments for Instrumental Methods, John Wiley \& Sons, 1984.

19. Alexandrove A, Budevsky O and Dimitrov A, J Radioanal Chem., 1976, 29, 243.

20. Kamurova S M, Talanta, 1992, 39, 997.

21. Nakamoto K, Infrared and Raman Spectra of Inorganic and Coordination Compounds, $3^{\text {rd }}$ Ed., John Wiley \& Sons, New York, 1978. 


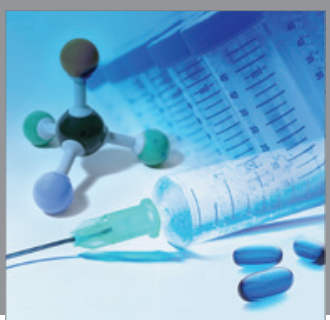

International Journal of

Medicinal Chemistry

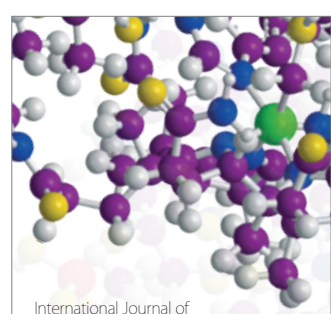

Carbohydrate Chemistry

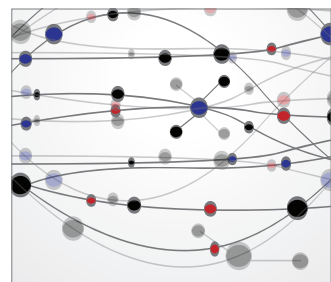

The Scientific World Journal
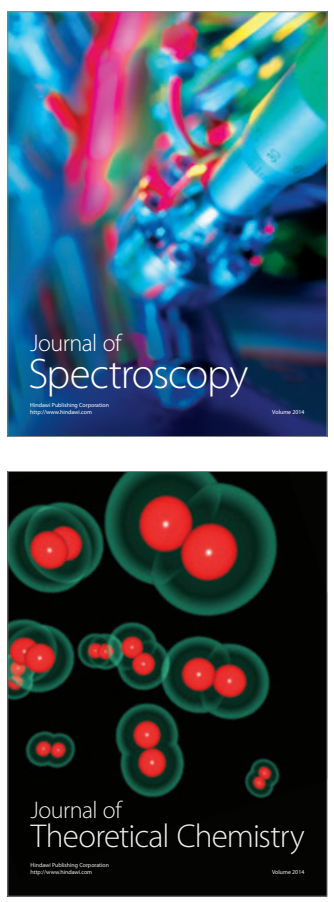
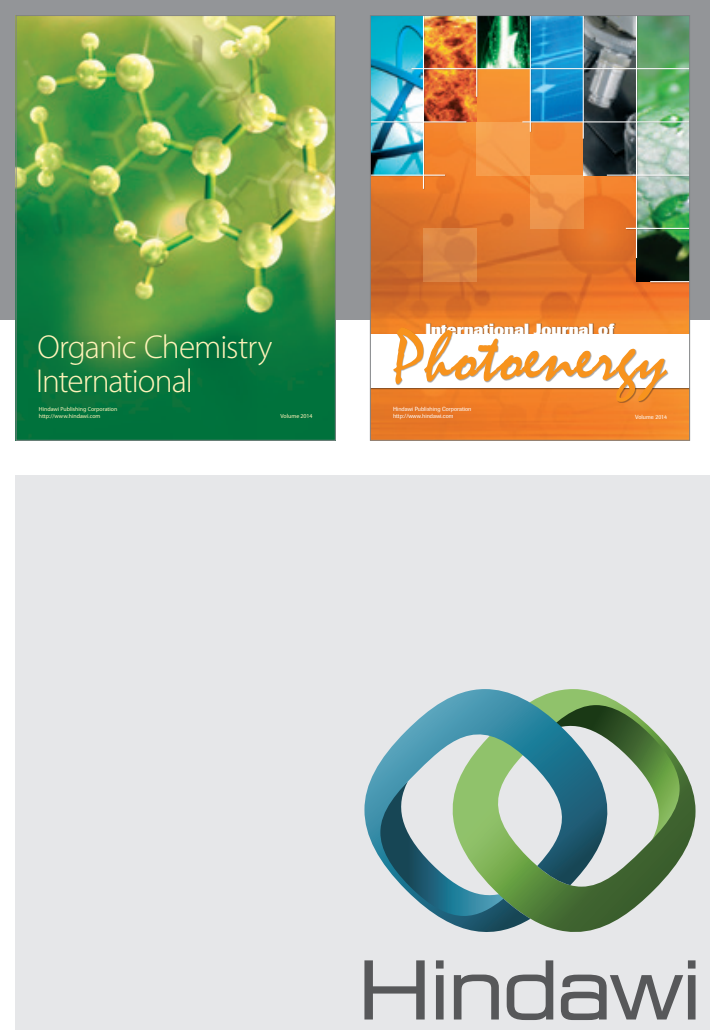

Submit your manuscripts at

http://www.hindawi.com
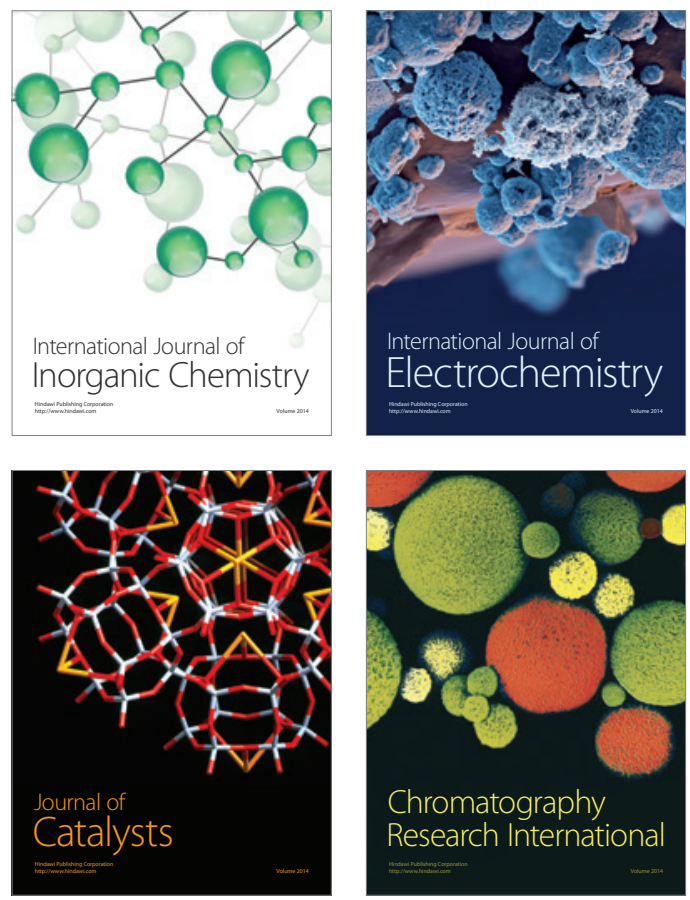
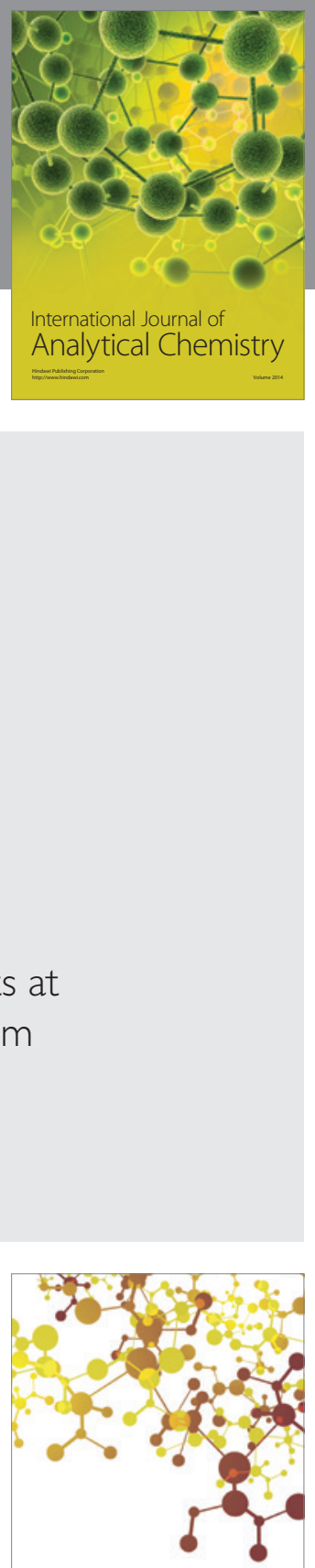

Journal of

Applied Chemistry
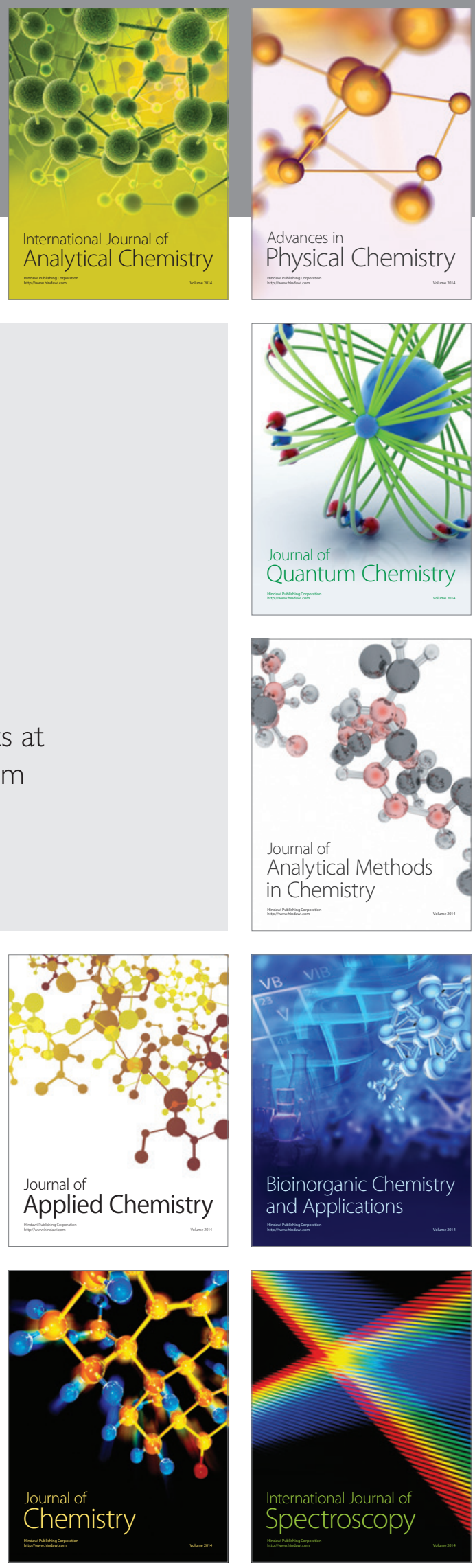